\title{
The affective factors influencing students' speaking ability
}

\author{
Illyin a,1,*, Gusti Nur Hanifah b,2, Sofi Yunianti c,3 \\ a,b Universitas Muhammadiyah Surabaya, Jl. Raya Sutorejo No.59, Dukuh Sutorejo, Kec. Mulyorejo, Surabaya, Jawa Timur 60113, Indonesia \\ c Universitas Surabaya, J1. Raya Rungkut, Kali Rungkut, Kec. Rungkut, Surabaya, Jawa Timur 60293, Indonesia \\ 1.illyin41@gmail.com*; ${ }^{2}$ gustihafifah@gmail.com; ${ }^{3}$ sofiyunianti@fkip.um-surabaya.ac.id \\ * corresponding author
}

\section{ARTICLE INFO}

\section{Article history}

Received 25 December 2019

Revised 16 March 2020

Accepted 8 August 2020

Available Online 15 January 2021

Keywords

affective factors

motivation

anxiety

self-confidence

speaking ability

\begin{abstract}
Considering speaking ability is one of the important abilities that students have to master in learning English. However, most of their speaking ability is low. It is caused by several factors, one of those factors is affective factors (motivation, anxiety, and self-confidence). The research aims to know what affective factors that mostly influence students' speaking ability. This research applied quantitative design with simple linear regression analysis. The sample of the research is 39 students from two classes X science class and X social class at SMA Muhammadiyah 9 Surabaya. Questionnaire and speaking test used as the instrument of the research. The result of the speaking test showed that the students' speaking ability is below average. It is proven by the scores of students speaking tests are mostly below the minimal completeness criteria that is said by the school. The result shows that among three affective factors, the most influential factor is self-confidence, and the second influential factor is motivation. Meanwhile anxiety is proven not to influence the students speaking ability. The findings show that the total significant value of motivation is 0,011 , anxiety is 0.063 , and self-confidence is 0.007 . It shows that speaking ability is influenced by motivation and selfconfidence, but the result of the regression test shows that anxiety does not influence students' speaking ability even though the data result of anxiety is appropriate with the theory of the research. It can be caused by various aspects such as students' characteristics, class atmosphere during the speaking test, and teacher attitude. So, the teacher should be fun when setting up the atmosphere of speaking, no pressure, and make students less anxious, so they don't feel to be tested and to be assessed.
\end{abstract}

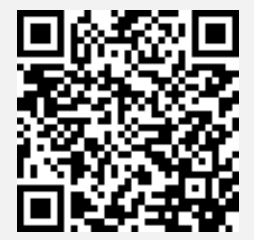

This is an open access article under the CC-BY-SA license.

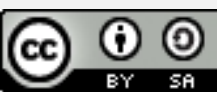

\section{Introduction}

Speaking becomes one of the most important skills in English because it can make people easily understand what things explained orally (Richard: 2008). Students' speaking ability is expected to be good because they have learned English since some years in the school and they will have many performances related to oral skill in the school or outside of school, but most of them may not be able to communicate smoothly and accurately because they lack the necessary knowledge. Related to the theory of Brown (2004) speaking can be observed directly and empirically because it is a productive skill and learners are considered to have good speaking performance if they have mastered the components in speaking such as grammar, vocabulary, pronunciation, fluency, and accuracy.

Not all language learners after years of learning English can communicate smoothly and accurately, they tend to have low performance when they have to communicate or speak in front of others. This phenomenon has become one of the problems in language learning today. Having good 
communication skills is very important. But, what is currently one of the most popular problems in language learning in Indonesia is that students tend to have low performance even though they have learned English for many years (Husnawati, 2017; Arta, 2018; Hasanah \& Utami, 2020) . This is caused by many factors that influence students' speaking ability such as performance conditions, affective factors, listening ability, topical knowledge, Feedback during speaking activities, and speaking problems. But this study focuses on affective factors that affect students' speaking ability (Tuan \& Mai, 2015).

However, studies proved that affective factors have considerable influence on students' speaking ability. The affective factor is the factor that deals with attitudes and values. It includes the nature of behavior such as feelings, interests, attitudes, emotions, values and so on. Affective factors are one of the most important factors that can affect a student's speaking ability. The affective side of students possibly influences the success or failure of language learning. Affective factors that also involve a person's emotions, feelings and behavior. Some affective factors are closely related to second language acquisition (Oxford,1990). Affective factors here include motivation, anxiety, and selfconfidence. A variety of affective variables has been confirmed to be related to success in second language acquisition in research over the last decade but most of those studies examined the three categories: motivation, self-confidence and anxiety (Krashen, 1982).

Motivation is an affective factor that encourages and directs behavior of students' speaking ability both encouragement from within the students itself or from outside and the environment. Motivation can affect students speaking ability because it will encourage students to pursue their goals in speaking ability. The higher motivation of learners in learning a second language, the higher possibility of their success in mastering the second language. However, second language learners who have low motivation will have difficulty to achieve success from learning. So, motivation is one of the factors that plays a role in influencing the success of second language learning. Another affective factor that can influence students' speaking ability is anxiety. One of the problems for students in learning a second language is that they get anxiety when they are told to speak in front of the class or speak with other people in English. The lower the students' anxiety, then their speaking performance will be higher. While the higher of students' anxiety in speaking English, then their speaking performance will be lower. Furthermore, self-confidence is also the component of affective factors that can influence students' speaking ability. If the students have high confidence, then they will have a high score in speaking and vice versa (Ni Hui, 2012; Tuan \& Mai, 2015).

To help students improve their speaking skills, teachers need to find ways to help them overcome the problems that they face. In addition, teachers also need to know the affective factors that affect students' speaking ability so that they can handle these factors to help students improve their speaking ability. However, until now, there is rarely research that has been conducted about these fields and at this time there is rarely research that discusses affective factors that affect a student's speaking ability but rather examines speaking skills and its general factors. There are also many studies that focus more on cognitive factors of students in acquiring a second language. While this research explores affective factors influences students' speaking ability.

Although several other studies related to this problem have been done, the researcher believes that there is always something new that can be found because the researcher wants to determine the differences between the implementation result of previous study and this research based on different context and situation. This research aims to define what are the affective factors that influence students' speaking ability and also to find out which affective factors most influence students' speaking ability.

\section{Research Method}

The researcher used a quantitative method to get the data and simple linear regression used to analyze the data. Quantitative method chooses because this research intends to see what affective factors influence speaking ability and what affective factors most influence speaking ability. By explaining the relationship between variables, it can determine whether one or more variables might affect other variables. Here the dependent variable is students' speaking ability while the independent variable is the affective factors. There are three independent variables that are motivation, anxiety, and self-confidence. In addition, this research analyzed statistically by using simple linear regression to determine the influence of each independent variable (affective factors) on the dependent variable 
(speaking ability) and to find out which independent variable is the most influential factor to dependent variable (Creswell: 2012).

The population of the research is all of the students at SMA Muhammadiyah 9 Surabaya in 2018/2019 which amounted to one hundred fifty four students. The researcher used purposive sampling to determine the sample of population. The sample of this research is two classes which contains 39 students in X IPA and X IPS class because those classes are the only data that can be taken as a sample in this research. The sample was given a questionnaire for each student to be filled. The questionnaire was the instrument to measure the students' affective factors. The researcher also conducted a speaking test to the students in order to determine the influence of affective factors on students' speaking ability. The speaking test was another instrument in this research to measure the speaking ability of the students. Data of this research has been through validity and reliability tests, then the researcher analyzed the data result from the questionnaire and speaking test result statistically by using simple linear regression. Finally, the researcher made conclusions based on the result of the analysis.

\subsection{Validity and Reliability Result of the Instrument}

Before the instrument was distributed to the sample of population, the researcher conducted a validation test on the instrument, where the researcher tested the questionnaire with two stages, namely by expert validation and validity and reliability test.

From the validity test table of the questionnaire in this research, it can be seen that all of the item questions got the sig value (2-tailed) $<0.05$ and the value of pearson correlation is positive. So it can be concluded that all of the questions item in the questionnaire is valid because it meets the validity requirements. While the results of the reliability test, it is known that the cronbach's alpha number is equal to 0,965 it means that greater than 0.06 . Therefore, it can be concluded that the research instrument used to measure the influence of affective factors on the speaking ability can be said that the data is very reliable.

\section{Findings and Discussion}

This research was conducted to determine the effect of affective factors toward students' speaking ability. The data in this research were divided into two parts. The first data was questionnaire data about affective factors which included motivation, anxiety, and self-confidence. The second data was the result of students speaking test. With the data obtained can be seen the effect of affective factors seen from the results of students' questionnaire on students' speaking abilities. To find out the data of students' speaking ability, it can be seen from the result of students' speaking test. While to find out the data of students' affective factors, can be seen from the results of the students' questionnaire which include motivation, anxiety, and self-confidence.

\subsection{Affective Factors}

Data about affective factors obtained from the result of the questionnaire that has been distributed by researcher to the respondents. The higher score for variable affective or variable $\mathrm{X}$ was 40 and the lower score was 10. Each statement was measured with a score of 1 to 4 . So that expected the lowest score was 10 and the highest score was 40 . From the score that has been obtained from the respondents were made interval class length that was 7 , so that it can be formed four classifications that are very low, low, high, and very high. The results of the students' affective factors classification (motivation, anxiety, and self-confidence) can be seen in Figure 1 as follows:

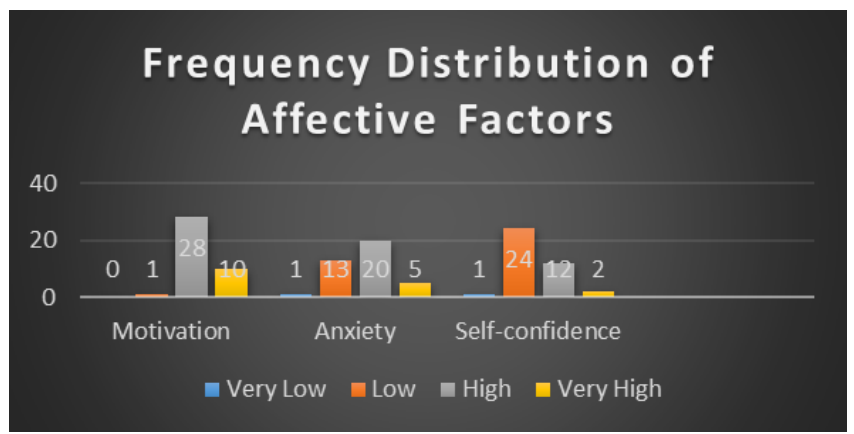

Fig. 1. Frequency Distribution of Affective Factors 
According to the graph above, it can be seen that among three affective factors the most classifications is the classification of high motivation with 28 students. While the lowest classification is the classification of very low motivation with there are no students included in this classification. Viewed from motivational classification, the highest classification is the students which include high motivation and the lowest classification is the students which include very low classification. Further, in anxiety classification, the highest classification is the students which include high anxiety and the lowest is the students which include very low classification. Seen from self-confidence, the highest classification is the students which include low classification while the lowest is the students which include very low classification.

\subsection{Speaking Ability}

The speaking ability of students who become the respondents in this research are mostly average with low scores. The results of the speaking test can be described as follows. The results of the respondents who got 80 were five respondents, the respondents who got the score 76 were only two respondents, for score 72 were four respondents, while the respondents who obtained the score below 70 were about 28 respondents. It means the respondents got lower scores than those who got a high score. In addition, according to information from the English teacher at the school who was the sample in this research, the minimal completeness criteria of English lessons was 75. So, based on the data in this research the respondents who obtained the score exceeded the minimal completeness criteria were only 7 respondents while the rest were respondents who obtained low scores or do not meet the minimal completeness criteria.

\subsection{The Affective Factors that Most Influence Students Speaking Ability}

Data about affective factors or variable $\mathrm{X} 1, \mathrm{X} 2$, and $\mathrm{X} 3$ obtained from the results of the questionnaire that have been distributed by the researcher to the respondents. The data has been through prerequisite test that are normality test, heteroscedasticity test, multicollinearity test, and linearity test. The results obtained from respondents were analyzed using an SPSS 2.1 programmer with simple linear regression test and the results can be seen in Table 1 below:

Table 1. Out-put of Regression Test toward Affective Factors Coefficients

Coefficients $^{\mathrm{a}}$

\begin{tabular}{ccccccc}
\hline \multirow{2}{*}{ Model } & \multicolumn{2}{c}{ Unstandardized Coefficients } & $\begin{array}{c}\text { Standardized } \\
\text { Coefficients }\end{array}$ & T & Sig. \\
\cline { 2 - 7 } & & B & Std. Error & Beta & \\
\hline & (Constant) & -.187 & 26.283 & & -.007 & .994 \\
1 & x1 & 1.318 & .490 & .348 & 2.687 & .011 \\
& x2 & -.799 & .417 & -.256 & -1.917 & .063 \\
& x3 & 1.499 & .523 & .363 & 2.869 & .007 \\
\hline
\end{tabular}

a. Dependent Variable: $Y$

Self-confidence is the most influential factor in speaking ability. It can be proven by the results of significant value in the self-confidence variable. In the regression test the significant value of variable self-confidence is 0.007 where that value is the smallest value among the three variables, because if the significant value is more less than 0.05 then the variable will be more influential. In this case it can be said that if students' self-confidence are higher, then students' speaking abilities will also be high. But, if students' self-confidence are lower, then students' speaking abilities will also be low because self-confidence of students is very influential toward students' speaking abilities. The previous study in this research Ni Hui (2012) argue that students with high self-confidence in learning English that they have competence to learn English well and as a result they will appear very active in class and their grades in English are high, and vice versa. Furthermore, Park \& Lee (2005) also stated that the higher self-confidence of students in speaking English, the higher oral performance they showed. These previous study results are the same as this research which if the students' selfconfidence are high, then their speaking abilities will also be high.

The second most influential factor in speaking ability is motivation. It can also prove by the results of significant value in the motivation variable. In the regression test the significant value of variable motivation is 0.011 where that value is the second smallest value among the three variables, because 
if the significant value is more less than 0.05 then the variable will be more influential. In this case it can be said that if students' motivation of English is higher, then students' speaking abilities will also be high. But, if students' motivation of English is lower, then students' speaking abilities will also be low because motivation of students is one of the factors that influence students' speaking abilities. Based on the result above can be said that this result is related to the theory used in this research which states that the higher motivation of learners in learning English, the higher possibility of their success in mastering English. But, learners who have low motivation will have difficulty to achieve success from learning English (Ni Hui: 2012).

Surprisingly anxiety in this research does not influence speaking ability. It can be proven by the results of significant value in the anxiety variable. In the regression test the significant value of variable anxiety is 0.063 where that value is the largest value among the three variables, the value cannot be said to be influential because it is higher than 0.05 . While significant value can be said to have an influence if the significance value is less than 0.05. Ni Hui (2012) mentioned that anxiety is also one of considerable impact on the students in English. It means if students have low anxiety then their abilities in speaking English will be high. But, if they have high anxiety then their abilities in speaking English will be low. It means the data of anxiety in this research already appropriate with the theory that has been said by Ni Hui (2012).

Referring to the data in this research, it can be seen that the students who have a high score will have low anxiety because if the students feel relaxed and have no anxiety when speaking English, it can make students get a high speaking score. But, the students who have high anxiety, they will get a low score because they feel unrelaxed when speaking English and it can have affected students' speaking ability. It means these findings related to the theory in this research that already mentioned the higher of student's anxiety, they will have lower speaking ability and the lower students' anxiety they will have higher speaking ability.

However, although the result of anxiety data is in accordance with the theory, the result of the regression test still shows that the value of anxiety is not significant or anxiety does not influence students' speaking ability. It can be caused by various aspects such as students' characteristics, class atmosphere during the speaking test, and it can also be caused by the teacher's attitude. Students' characteristics indicate that they were not concerned with English, it can be seen during the test many of them underestimate the speaking test and there were also some students who did not pay much attention during the speaking test. Moreover, the class atmosphere during the speaking test is not supportive as many students were busy by themselves with their friends and they were not very tense during the test. Despite the students being ignorant, they don't really get tense with the atmosphere of speaking test. Instead they don't feel threatened or stressed during the test that's why it might be one of the indicators why anxiety does not affect the speaking test. In addition, teachers' attitude determines the students' characteristics and class atmosphere. During the speaking test, the teacher was not that strict that makes the students worried about the test. The teacher managed the class atmosphere was still crowded and the teacher did not manage the class very well. Therefore, the classroom atmosphere has no pressure and makes students less anxious, so they don't feel to be tested and to be assessed.

\section{Conclusion}

Based on the results of this research, it can be concluded two things regarding the affective factors influence students' speaking ability.

First, according to the result of simple linear regression test in this research shows that the affective factors that influence students' speaking ability are motivation with a significant value of 0.011 and self-confidence with a significant value of 0.007 , while anxiety does not influence to student's speaking ability with a significant value of 0.063 .

Second, the most influential affective factor in speaking ability is self-confidence. Therefore, if students are more confident, the speaking abilities of students will also be higher. But, if students are less confident, the speaking abilities of students will also be lower, it means self-confidence influences students' speaking abilities. The second most influential factor in students speaking ability is motivation, thus if students have high motivation, their speaking abilities will also be higher. However, if students have low motivation, their speaking abilities will also be lower because motivation of 
students influences their speaking abilities. The result shows that anxiety does not influence students' speaking ability; it can be due to students' characteristics, and teachers' attitudes when setting up the speaking test. Further in depth study needs to be done why each aspect influences students speaking ability because this study is done quantitatively. Therefore further in depth study needs to be done to find out in detail why each factor influences students' speaking ability.

\section{References}

Arta, B. (2018). Multiple studies: The influence of collaborative learning approach on Indonesian secondary high school students' English-speaking skill. English Language Teaching Educational Journal (ELTEJ), I(3), 149-160.

Brown. (2004). Language assessment principle and classroom practices. California: Longman.

Creswell, J. W. (2012). Educational research design: Planning, conducting and evaluating qualitative and quantitative research: Fourth edition. Boston: Pearson.

Hasanah, N., \& Utami, P. (2020). Emerging challenges of teaching English in non-native English-speaking countries: Teachers' view. English Language Teaching Educational Journal, 2(3), 112-120.

Husnawati. (2017). Students' speaking performance: Some challenging factors. (S1 Thesis). Universitas Islam Negeri Ar-Raniry Darussalam. Banda Aceh.

Krashen, S. D. (1982). Principle and practice in second language acquisition. New York: Pergamon Press.

Ni Hui. (2012). The Effects of affective factors in SLA and pedagogical implications. Journal Theory and Practice in Language Studies, 2(7), 1508-1513. Finland: Academy Publisher.

Oxford, R. L (1990). Language learning strategies: What every teacher should know. New York: Newbury House Publisher.

Park, H., \& Lee, A. R. (2005). L2 learners' anxiety, self-confidence, and oral performance. Proceedings of the 10th Conference of Pan-Pacific Association of Applied Linguistics, 107-208. Edinburgh University. Retrieved January, 4th, 2017 from http://www.paaljapan.org/resources/proceedings/PAAL10/pdfs/hyesook.pdf.

Richards, J. C. (2008). Teaching listening \& speaking to practice. Cambridge: Cambridge University Press.

Tuan, N. H., \& Mai, T. N. (2015). Factors affecting students' speaking performance at Le Thanh Hien high school. Asian journal of educational research, 3(2), 8-23. 